\title{
Den dobbelte referenceramme - Kronprinsessan på dansk og svensk
}

\author{
Af Gunhild Agger
}

Det konsbetonede politiske drama, der gennem de sidste år har ligget underdrejet, er med Kronprinsessan blevet genopdaget. Artiklen tager udgangspunkt $i$ den danske og den svenske medieoffentlighed, der udspillede sig i forbindelse med modtagelsen i foråret 2006. I begge tilfelde er det påfaldende, at anmeldere og journalister inddrager virkelighedens politiske liv som referenceramme. Skont de nationale kontekster er forskellige, opviser modtagelsen släende ligheder. Virkelighedsreferencerne relateres til Hanne-Vibeke Holsts nogleroman, Kronprinsessen, der også er oversat til svensk. Artiklen analyserer på den baggrund romanens og tv-foljetons realismestrategier, giver et signalement af de genremassige slagtskaber og profilerer den dobbelte referencerammes problematik og etik.

\section{Karlighed, karriere og medieoffentlighed}

Tv-føljetonen Kromprinsessan ${ }^{1}$ (1-4) blev udsendt samtidig i Sverige og Danmark. I Sverige på SVT over 4 mandage d. 27.2.-20.3. 2006 og på DR 1 over fire søndage d. 5.3.-28.3. 2006. Kronprinsessan var grænseoverskridende ved at være en svensk produktion på baggrund af et dansk roman-forlæg og med dansk instruktør. Den gav stof til heftig debat om ligestilling og politik, 'kærlighed og karriere', i anmeldelser, interviews og omtale i pressen og på internettet, både i Danmark og i Sverige. Kronprinsessan modtog SVTs jämställdhetspris Prix Egalia i august 2006. Jeg vil argumentere for, at en væsentlig grund til Kronprinsessans debatprovokerende effekt er, at den både i dansk og svensk sammenhæng trækker på en dobbelt referenceramme, der - i lighed med romanen - ubesværet blander mediefremstillinger og virkelighedsreferencer fra både det politiske liv og det private hverdagsliv ind i fiktionen. Personer, begivenheder og forhold, der gennem medierne er kendte fra virkeligheden, er monteret sammen i forskellige brudstykker, iscenesættelser og forklædninger. Hvordan er emnet for det følgende.

Alle de banale samlivsproblemer, der skal løses, hvis tilværelsen skal fungere, bliver vendt i Kronprinsessan. Eftersom Kronprinsessan foregår i det politiske liv, antager konflikterne politiske dimensioner. Det kommer til at handle om at finde »sandheden«
- er der reelt ligestilling i de nordiske velfærdssamfund? Er der overensstemmelse mellem politikken og den måde, politikerne lever på? Og i hvor høj grad er mediernes formidling gyldig?

Jeg tager udgangspunkt i den medieoffentlighed, der udspillede sig i forbindelse med modtagelsen af Kronprinsessan. Jeg har gennemgået anmeldelser, interviews og omtale fra perioden d. 25.2.-30.3.2006 i Information, Politiken, BT og Dagens Nyheter, Aftonbladet og Ekspressen. Forskellige avistyper er således repræsenteret i begge lande. Jeg citerer en række eksempler, der viser, hvordan sammenkoblingen typisk sker. Enkelte andre inddrages undervejs, når det forekommer særligt belysende. Jeg har desuden fulgt debatten på Kommunikationsforum.dk.

Både i den danske og den svenske offentlighed er det nærliggende at relatere til virkelighedens politiske liv. Trods de ligheder i modtagelsen, dette resulterer i, er der en forskel på svensk og dansk forståelse og håndtering af ligeberettigelse, som jeg vil karakterisere. Det er min antagelse, at denne forskel danner baggrund for, at romanen blev adapteret i Sverige og ikke i Danmark. I den danske offentlighed har virkelighedsreferencerne først og fremmest bund i Hanne-Vibeke Holsts roman. Jeg diskuterer derfor Kronprinsessens karakter af nøgleroman, idet det er min opfattelse, at denne bidrager stærkt til den realitetsfornemmelse, der kunne registreres i modtagelsen af tv-føljetonen. Samtidig var nøglen så universel, at den let kunne oversættes 
til svensk. Det er påfaldende, at roman og tv-føljeton benytter de samme realismestrategier.

I 1970erne mente man, at »handling gi'r forvandling «, og at litteraturen skulle engagere sig i samfundets mest påtrængende spørgsmål. Det er bemærkelsesværdigt, at det kønsbetonede politiske drama, der gennem de sidste mange år har ligget underdrejet, med Kronprinsessan er blevet genopdaget. Det er en genre med store traditioner for at iscenesætte virkelighedsreferencer, og jeg giver derfor et signalement af genremæssige slægtskaber og placerer Kronprinsessan i forhold til dem. Formålet er at profilere den dobbelte referencerammes problematik og etik i forhold til samfundsengagementet.

\section{Fiktion - virkelighed retur}

Hver dag møder vi kendte mennesker i medierne. Hvilken form, dette møde tager, er afhængigt af både de kendtes status og mediernes karakter. Den skelnen mellem offentlig og privat sfære, der konstituerede sig med den borgerlige offentlighed, har i mange år levet af konstante afprøvninger og omdefineringer, der til stadighed flytter grænserne. Kabel og Sparre gennemgår i Den glade journalistik Pressenævnets holdning til uønsket omtale af kendte menneskers privatliv og konstaterer, at Pressenævnets fortolkning i 2000 er bredere end tidligere i 1990erne. De kendte må »tåle en omfattende omtale i medierne« (Kabel og Sparre, 2001, s. 164).

Medieoffentligheden i forbindelse med Kronprinsessan opviste et eksempel på flydende grænser $\mathrm{i}$ den forstand, at medieformidlet fiktion og fakta hele tiden blev blandet i den offentlige debat. Det skete på en helt selvfølgelig måde, der satte de traditionelle fiktions- og faktakontrakter ud af kraft. Den svenske produktion blev solidt forankret i en dansk sammenhæng, og der blev trukket en række paralleller mellem fiktionen og den medieformidlede virkelighed.

\section{Den danske medieoffentlighed}

Der var foromtale i Politiken under overskriften »Politiske kronprinsesser fryser på toppen - i virkeligheden og i ny tv-serie« (d. 4.3.2006). I foromtalen forbandt journalisterne ubesværet fiktionens politiske misere med aktuelle danske, kvindelige politikere ved at indhente kommentarer fra den radikale minister for udvikling i den sidste Nyrup- rokade, Anita Bay Bundegaard, social- og ligestillingsminister Eva Kjer Hansen (V) og formanden for Socialdemokraterne Helle Thorning-Schmidt. Og de tværpolitiske kommentarer bekræftede, at medierne er med til at fastholde bindingen mellem kvinder og privatliv frem for politik - også, når kvinderne rent faktisk er toppolitikere: »Der bliver fokuseret meget mere på, hvordan man håndterer ting på hjemmefronten. For eksempel bliver jeg ofte inviteret til at tale om, hvordan det er at være mor og minister. Mandlige kollegaer kommer ikke ud for at tale om, hvordan det er at være far og minister «, citeres Eva Kjer Hansen for at sige (Politiken 4.3.2006).

Anita Bay Bundegaard-sporet blev fulgt op i en række interviews og omtaler. Under overskriften »Jeg måtte kæmpe for magten hver dag « fremhævede Anita Bay Bundegaard i et interview med Sarah Skarum i B.T. d. 19.3.2006 en række træk i Kronprinsessan, der er som taget ud af hendes ministertid. Listen er lang og rummer bl.a. følgende træk:

- at hun var minister i elleve måneder,

- at hun blev modtaget med en blanding af »fascination, frygt, misundelse og nedladenhed «,

- at hun ændrede stil i sin ministerperiode (»Jeg fik lynhurtigt prædikatet langt lyst hår og blå øjne. [...] Derfor klippede jeg hurtigt mit lange hår«),

- at en af hendes mandlige ansatte under et møde i Bruxelles blev antaget for at være ministeren,

- at Lotte Bundsgaard og hun blev kaldt »Nyrups julepynt«,

- at deres evner til at tackle privatlivet blev fremhævet i modsætning til, hvad der var tilfældet for mandlige politikere (»Jeg siger ikke, at det er sværere at være kvinde, men man har andre vilkår«),

- at hendes privatliv blev ændret gennem det øgede mediefokus (»Man afskaffer sit privatliv«), og

- at spontaneitet og ærlighed skaber mistro og modvilje (»Stiller man et åbent spørgsmål, så tænker folk, - hvad har hun gang i?« (B.T. d. 19.3.2006).

Når jeg citerer så omfattende, skyldes det, at der her er tale om en omfattende intertekstualitet. Alle de nævnte træk er indoptaget og genbrugt i både romanen og tv-føljetonen. For den seer, der kender forhistorien, er de altså med til at forankre fiktionen i genkendelige forhold, der tidligere har været i pressens søgelys. For ældre læsere og seere klinger 
yderligere et lag fra 1970erne med i erindringen. Ritt Bjerregaard er den fremmeste repræsentant for det. En af de spektakulære manifestationer af dette lag var opholdet på hotel Ritz i Paris under et UNESCO-møde. Efter en hårdhændet pressekampagne blev Ritt Bjerregaard i 1978 tvunget til at træde tilbage som undervisningsminister. Også ved andre lejligheder overtrådte hun codex og gik eller blev gået fra sine poster - men fik hver gang politisk come-back.

Kronprinsessan lagde i Danmark ud med et seertal på 1.098.000 og sluttede med 860.000 (Gallups TV-meter). De svenske seertal er parallelle og foretog samme bevægelse, idet 1. afsnit havde 1.475.000 seere og sidste 1.200 .000 (Kilde SVTdrama). ${ }^{2}$ De kvindelige seere tog tv-føljetonen til sig i højere grad end de mandlige. Når seertallene i begge tilfælde faldt markant efter 1. del, kan det have sammenhæng med, at dramaturgien i de to midterdele, der havde de laveste seertal, truede med at blive rigeligt forudsigelig.

Der var anmeldelser i stort set samtlige danske aviser, især efter første og sidste del. Anmelderne trak uafladeligt forbindelser til virkeligheden, ikke mindst ved at fremhæve forbindelsen til mulige kvindelige politikere. Birgitte Grue i B.T. betonede således, hvilke klare konsekvenser for indsigten i den politiske verdens mekanismer, det havde at se føljetonen: »At se Kronprinsessen er at forstå, hvorfor der er så få kvinder i toppolitik: kvinderne vælges på deres åbenhed og ærlighed - netop de impulsive egenskaber, som snart knuser dem i det politiske spil med dets fordækte magtkampe og skjulte dagsordener« (B.T. d. 3.2006).

Gennemgående blev føljetonen positivt modtaget, men med markering af et vist forbehold, der tog form af ambivalens. På den ene side blev modstillingen mellem den oprigtige miljøminister og regeringens "gamle, trætte mænd« (del 1) ifølge Morten Piil fremstillet på en måde, der var »svært underholdende« (Information d. 6.3.2006). Også Birgitte Grue betonede underholdningsværdien i anmeldelsen ovenfor.

På den anden side var der tale om en problemstilling, der i al sin genkendelighed forekom rigeligt stereotyp: »den sandhedssøgende kvinde-idealists svære politiske vilkår i et nordisk demokrati, der styres af pragmatiske han-ræve med større sans for kompromis og karriere end for konfrontation og karsken bælg« (Morten Piil, Information d. 29.3.2006). Var Charlotte Ekeblad i Alexandra
Rapaports udgave for smuk, ædel og rigtig til at kunne illudere realpolitiker? I Weekendavisen udfoldede Bo Bjørnvig en hel klumme under titlen »Udseendet imod sig« (d. 10.-16.3.2006). Heri harcelerede han over, at kvinder, der - med Hanne-Vibeke Holsts egne ord - ikke vil bedømmes på deres »udseende«, men på deres »karakter«, repræsenteres af netop den smukke og karismatiske Alexandra Rapaport. Morten Piil fremhævede dog også, at der skete en nuancering i portrættet af Charlotte Ekeblad, og at den afsluttende del bød på flere positive overraskelser.

Dette dilemma fik en særlig drejning på Kommunikationsforum.dk, hvor redaktionen tydeligvis følte sig provokeret af Kronprinsessans feministiske holdning: »Lige så politisk korrekt billedet af Charlotte er, lige så fordomsfuldt og dumsmart feministisk er det karikerede billede af hendes snothvalp af en mand. Rollerne er byttet om, men fordommene består« (Kommunikationsforum.dk d. 21.3.2006). På netstedet udspandt der sig herefter en debat, der med udgangspunkt i Kronprinsessan og/eller Hanne-Vibeke Holst som feministisk debattør forholdt sig til kvinders og mænds situation i dag, hvad angår karriere, kærlighed og ligestilling.

\section{Den svenske medieoffentlighed}

Dansk presse fremhævede Bundegaard som en oplagt model for Holsts miljøminister. Men for svensk presse var det ikke svært at finde svenske pendanter. Tanken på udenrigsminister Anna Lindh var umiddelbart nærliggende, da Holsts roman udkom på svensk i 2003. ${ }^{3}$ Anna Lindh var miljøminister i Ingvar Carlssons socialdemokratiske regering 1994-98 og gjorde et stort arbejde for at få europæisk fodslag i forhold til kemisk forurening og syreregn. Mona Sahlin, minister for bæredygtig udvikling i Göran Persson-regeringen, blev fremhævet som model i forbindelse med tvføljetonen. ${ }^{4}$ Mona Sahlin havde allerede en lang karriere bag sig, bl.a. som minister, da hun i 1995 kandiderede til posten som partileder, efter at Ingvar Carlsson havde meldt sin afgang. Efter den såkaldte Tobleroneaffære, der handlede om brug af et officielt kreditkort til private formål, trak hun sit kandidatur. Selv om der ikke var tvivl om, at hun havde handlet ukorrekt, kom affæren meget belejligt for Göran Persson, der blev valgt som formand. I 2007 lykkedes det Mona Sahlin at blive formand for de svenske socialdemokrater. 
Jan-Olov Andersson fremhævede i Aftonbladet realismen som årsag til, at det politiske drama generelt fungerer godt. Ifølge Andersson var der en høj »igjenkänningsfaktor«: »Intriger på jobbet och kvinnors val mellan karriär och familj kan ju de flesta identifiera sig med. Särskilt när det er välgjort som här, in i minsta detalj« (Aftonbladet $\mathrm{d}$. 27.2.2006). Skønt mere kritisk over for sammenhængen mellem det storpolitiske og det privatpolitiske niveau har Leif Furhammer i Dagens Nyheter samme indfaldsvinkel i sin anmeldelse: "Parallellerna till verkligheten fortsätter att vara bestickande, och inte minst mediernas tvetydiga roll i det politiska intrigspelet har utmanande likheter med den svenska samtidshistorien." (Dagens Nyheter d. 1.3.2006). I den afsluttende anmeldelse i samme avis er overskriften: »Kronprinsessan regerar. Äntligen en sann bild af livspusslet«. Åsa Beckman mener i modsætning til Leif Furhammer, at Kronprinsessan har været "rena terapin för alla kvinnor som forsöker få ihop ett ekspansivt yrkesliv med den lika vigtiga kärleken till man och barn" (Dagens Nyheter d. 30.3.2006). Ekspressens Britta Svensson ser derimod i en anmeldelse af aftenens tv problematikken i Kronprinsessan som forældet; den hører mere hjemme i 1990erne end i aktuelle svenske regeringskredse (Ekspressen d. 28.2.2006). ${ }^{5}$ Men heller ikke i Ekspressen står vurderingen alene. Dagen forinden har en anden anmelder fremhævet genkendelsesfaktoren: »Vi har genom åren sett regeringens kronprinsessor - Mona Sahlin, Margot Wallström och många andre. Även om Alexandra Rapaports minister inte ër hämtad från verkligheten så går mycket att känna igen -" (Bernt Eklund i Ekspressen d. 27.2.2006).

Betoningen af identificerbare forlæg i virkeligheden, nærhedsfaktoren og det genkendelige er således fællesstof hos danske og svenske anmeldere - ligesom en klart markeret uenighed om kønsproblematikkens relevans.

\section{Ligestilling på dansk og svensk}

Baggrunden for denne uenighed kan findes i ligestillingspolitikkens forskellige historie i Sverige og Danmark. Samfundsforsker Anette Borchorst har analyseret skandinavisk ligestillingspolitik. Hun opstiller to yderpositioner: »Som det ene yderpunkt var det svenske ligestillingsprojekt det mest partiorienterede, og det blev præget af stærk institutionalisering og udbredt styringsoptimisme«
(Borchorst, 2006, s. 267). Det gjaldt vel at mærke alle politiske partier. »Det andet yderpunkt var det danske ligestillingsprojekt, der var drevet frem af en græsrodsorienteret proces, katalyseret af en stærk udenomsparlamentarisk kvindebevægelse, der mobiliserede mange kvinder og havde stor betydning for forandringer i kvindesyn og familiestrukturer. Den distancerede sig fra statsmagten, og berøringsangsten var gensidig « (ibid.). Det norske ligestillingsprojekt placerede sig mellem disse positioner.

Det er en nærliggende antagelse, at den stærkere officielle svenske profilering af ligestillingsprojektet var baggrund for, at man i Sverige var mere interesseret $i$ at erhverve rettighederne til filmatisering af Kromprinsessen end i Danmark. Ifølge HanneVibeke Holst var Kronprinsessen oprindeligt tænkt og udformet som synopsis til tv-drama. Det har haft betydning for »de skiftende synsvinkler (povs), tempoet og montageteknikken « i den roman, hun i sidste ende valgte at skrive. Overføringen til tvmediet skulle på den baggrund ikke frembyde de store vanskeligheder. TV-Drama fik da også i 2002 romanen til gennemlæsning med henblik på tvadaption, men afslog i brev af 17.6.2002. ${ }^{6}$ Afslaget var ikke begrundet $\mathrm{i}$ romanens feminisme, men $\mathrm{i}$, at »romanens rigt facetterede skildring af konkrete handlinger og udsagn - gennem et imponerende væv af perspektivskift og sidehistorier - [...] ikke lader sig reducere så meget, som en adaption vil kræve«.

Den svenske producent Anna Cronemann havde ikke tilsvarende betænkeligheder, da hun i samarbejde med Produktionsselskabet Svensk Filmindustri og senere sit eget produktionsselskab Bobfilm, førte projektet ud i livet. Anna Cronemann havde ambitioner om at sammensætte et hold med et feministisk engagement. ${ }^{7}$ I den sammenhæng kom Katrine Windfeld ind i billedet. Efter en række år primært som instruktørassistent for bl.a. Ole Christian Madsen og Niels Arden Oplev fik hun her en stor, selvstændig opgave sammen med en række andre kvinder i samme situation som hun selv. ${ }^{8}$ I forlængelse heraf har Katrine Windfeld defineret Kronprinsessan ikke blot som et feministisk projekt, men som sin generations historie: »Vi er alle kvinder med forholdsvis store job og forholdsvis små børn.[...] Det var eksistentielt vigtigt for os at fortælle den her historie, som i virkeligheden er vores generations historie « (Information d. 3.3.2006). 


\section{Nøgleroman og realisme}

Modtagelsen viste for det første, at Kronprinsessan rummede et stort debatskabende potentiale. For det andet, at den satte gang i debatten på en måde, så debattørerne umiddelbart refererede til virkelighedens politikere og deres medieafhængige betingelser. Anmeldere såvel som politikere og journalister opførte sig ligesom dengang i 1970erne, eller for den sags skyld 1870erne, da litteraturen så det som sin fornemste opgave at sætte problemer under debat.

Når overførslen til det virkelige livs problemer og aktører foregik så ubesværet, som tilfældet var i omtale og anmeldelser, skyldes det i høj grad, at forlægget Kronprinsessen benytter sig af en række realismestrategier, herunder nøgleromanens. På den måde aktualiseres tematikken som del af modtagernes samtidige horisont. Parateksten til Kronprinsessen 2002 angiver, at det drejer sig om en »Roman«. På kolofonsiden skriver Hanne-Vibeke Holst »Tak til alle dem, der ved deres udstrakte velvilje og generøse åbenhed har gjort det muligt for mig at skabe denne fiktion, som måske ligner, men ikke er, et aftryk af virkeligheden«. Netop i forbindelse med fiktion, som i et eller andet omfang virker genkendelig, er det en traditionel strategi at sløre sporene på denne helt generelle måde, ikke mindst af hensyn til eventuelle sagsanlæg. Betegnelsen nøgleroman genfindes på andre sprog (Schlüsselroman, roman à clef, en betegnelse, der også bruges på engelsk). Den angiver ifølge Gero von Wilpert en roman, hvori virkelige begivenheder, tilstande og samtidige eller historiske personers skæbner fremstilles under ændrede navne og omstændigheder, så de er genkendelige for de vidende (Wilpert, 1964, s. 626). Den læser, der ikke har nøglen, går altså glip af det ekstra lag, der ligger i genkendeligheden.

Nøgleromanen knytter sig til en særlig form for realisme. Generelt bruges realismebegrebet enten som en ahistorisk stilbetegnelse eller som en betegnelse for en bestemt periode og dens stil. I film og tv-drama anvendes realismebegrebet desuden som et samlebegreb for en bestemt genretradition, karakteriseret af en særlig opmærksomhed på sociale og psykologiske faktorer og en vis uforudsigelighed i tilrettelæggelsen af forløbet og ikke mindst udgangen på det. Hvor komedier slutter godt $\mathrm{og}$ tragedier skidt, er den åbne slutning typisk for realismetraditionen (jf. Langkjær, 2002).

Forestillingen om realisme er ikke ny. I sin gen- nemgang af Aristoteles' mythos-begreb fremhæver Jørgen Holmgaard, at et afgørende kriterium for sammenkædningen af enkelthandlinger er kausalitet. Begrebet om narrativ kausalitet ser han som en forudsætning for realismebegrebet (Holmgaard,1998, s. 213 ff.). Ligesom i litteraturen har narrativ kausalitet spillet en stor rolle i realistisk film og tv-drama. Tilrettelæggelsen af handlinger, der udløser andre handlinger som en logisk konsekvens, er uden tvivl medvirkende til, at realismetraditionen har været så dominerende i film og tv-drama. Årsag og virkning er tæt forbundne.

Inden for litteraturen fremhævede Georg Brandes og Georg Lukács samstemmende det særlige i det typiske gennem deres definitioner af realisme. Det drejer sig med andre ord om detaljen. Billedmediernes evne til at fastholde den godt sete detalje gennem nærbilleder, der sætter sig på nethinden og afslører en bestemt sammenhæng, er en anden grund til realismens styrkeposition. Blikket for detaljen rummer det typiske moment i miljø og karakterer og dermed det genkendelige. Ikke for ingenting anvendes begrebet 'genkendelse' - som vi har set - hyppigt i forbindelse med populære tvdramatiske produktioner.

I forbindelse med detaljen kan det være en hjælp at skelne mellem forskellige analysefelter. Detaljen kan befinde sig på mange forskellige niveauer, og det er vigtigt at gøre sig klart, hvilken kontekst det drejer sig om. Forankring i konkret genkendelige tider og steder er grundlæggende i opbygningen af realisme - i modsætning til f.eks. surrealisme, absurdisme eller fantastik, hvor metaforiske eller symbolske tids- og stedbegreber er overgribende. Tids- og stedrealisme er forudsætninger for at skabe den genkendelighed i miljøer og karakterer, anmelderne refererer til.

\section{Realismestrategier i romanen og tv-føljetonen}

Nærheden til nutidens politiske virkelighed og dermed det autentiske præg fremkommer i roman og tv-føljeton ved hjælp af en femstrenget strategi, hvor tid og sted, narrativ kausalitet og sans for detaljen kombineres på flere måder.

For det første er der en detaljeret steds- og tidsrealisme. Den første dag som miljøminister står Charlotte Damgaard og ser ud over Højbro Plads: »Juletræssælgeren havde tændt sin ophængte lysguirlande under markisen, københavnerne ha- 
stede afsted ovre på Strøget, en lirekassemand stod og spillede julesange under det gule McDonaldslogo på hjørnet til Købmagergade, og døren til Café Norden gik uophørligt op og i« (Holst, 2003, s. 68). Gader og steder angives præcist, og små detaljer som f.eks. juletræssælgerens guirlande virker overbevisende.

Steds- og tidsrealismen făr i tv-føljetonen visuel kraft gennem fotograferingen af 'magtens korridorer' gennem den distancerede kameravinkel (fotograf: Jonas Alarik). En anden forankrende detalje er panoreringerne ud over Stockholm, der fungerer som pusterum og overledning, ofte akkompagneret af en diskret underlægningsmusik. $\mathrm{Vi}$ ser byen i morgen- og aftenbelysning, og vi følger den med årstidernes skiften, hvilket er med til at markere dagligdagens fortløbende tid. Vi ser traffikmylderet omkring stationerne i øjenhøjde, og vi ser Stockholms gader og pladser fra ministerkontorerne omkring Riksdagshuset i fugleperspektiv. Panoreringerne giver visuelt en forklaring på, hvorfor politikerne handler, som de gør, og hvorfor de klynger sig til magten: Byen er blændende smuk, og det er også en æstetisk tilfredsstillelse at bestemme over den.

For det andet er sproget i begge tilfælde daglig- $o g$ talesprogsnert, og ordvalget viser kendskab til diverse former for professionel sprogbrug. Som nyudnævnt minister skal Charlotte f.eks. i gang med »ruskurset« (ibid.), og kort efter gennemgår hun med ministersekretæren »Q's \& A's« (op. cit., s. 85). I det hele taget er den engelsksproglige jargon, der behersker vore dages sprog, omhyggeligt indfanget. Det gælder dagligsprogets anvendelse af udtryk som 'fuck' og citater som »let us cut the bullshit« (op. cit., s. 66) eller »Life is a bitch and then you die« (op. cit., s. 298). Det gælder også det professionelle sprogs jargon, f.eks. »empowerment« (op. cit., s. 234). De mest anvendte politiske klicheer er markeret sprogligt: »Så slap de for at formulere den med et vigtigt signal at sende« (op. cit., s. 197) og »damebladenes banale kvindekonflikt mellem 'kærlighed og karriere' (op. cit., s. 298).

For det tredje refereres der til en række begivenheder, der faktisk har fundet sted, om end ikke nødvendigvis i den sammenhæng, som fiktionen tildeler dem, eller på det angivne tidspunkt. Det drejer om alt fra ministerrokade og de forskellige partiers politiske stillingtagen til deltagelse i notorisk afholdte møder i Bruxelles, Paris og New York; fra stiftelsen af ATTAC til EU-topmødet i
Göteborg og G 8- mødet i Genova; fra mediernes afdækning af uenigheder i den socialdemokratiske folketingsgruppe til indmonteringen af konkrete træk som misbrug af officielle kontokort og snagen i politikernes privatliv, herunder pressens fokus på kvindelige ministres udseende, hvordan de får passet deres børn og lever sammen med deres mænd. Desuden indgår en række elementer, inspireret af hhv. Svend Aukens og Anna Lindhs miljøpolitik. I gengivelsen af begivenhederne præciseres det altid, hvilket medie, der er tale om, og dermed står medierepræsentationen stærkt - ligesom den for de fleste mennesker gør det i virkeligheden. Politikere er som bekendt mere kendte fra medierne end fra vælgermøder. Det virker derfor autentisk, at Charlotte Damgaard på skift optræder i FyllandsPosten, Politiken og Sondagsmagasinet - og Ekeblad i de modsvarende svenske medier. Der skal særlig kvalificeret indsigt til at gennemskue og beherske mediernes ageren i alle led. Dette niveau er systematisk til stede gennem de indslag fra journalister, politiske modstandere eller kommentatorer, der - grafisk udskilt - kommenterer slagets gang fra sidelinjen.

For det fjerde afsætter den narrative kausalitet sig i dramaturgien. Fiktionen er udspændt i tid mellem optaktens udnævnelse til og slutningens fald som minister. Dramaturgien pointeres af ministerchaufføren: »Der er to ture, en minister aldrig glemmer. Den første og den sidste.« Ministerchaufførens synsvinkel har en speciel betydning. Ministre forgår, mens ministerchauffører består. Altså ser han udviklingen i bakspejlet, der giver ham mulighed for at fremhæve tidens rytme fra begyndelse til slutning.

For det femte kan en række genkendelige politikere ses som modeller for fiktionens karakterer. $\mathrm{Og}$ det er naturligvis her, nøgleromanens dubiøse træk træder i funktion, og hvor dens virkelighedsrelation kan blive kontroversiel. For en dansker er Anita Bay Bundegaard oplagt som forlæg for Charlotte Damgaard. Der kan samtidig, som både danske og svenske anmeldere har gjort, nævnes en lang række andre tidligere og nuværende kvindelige politikere som mulige inspirationskilder.

At udenrigsminister Elizabeth Meyer ligner Ritt Bjerregaard i udseende, gennemslagskraft og livsstil er ubetvivleligt. Tilsvarende optræder der hos finansminister Gert Jacobsen træk, der minder betydeligt om karakteristiske træk hos Mogens Lykketoft. Bag Per Vittrup skjuler der sig talemåder og 
handlinger fra Poul Nyrup Rasmussen osv. Men i alle tilfælde er der indlagt træk, der taler imod fuldstændig identifikation, og det har været nemt at finde slående svenske paralleller.

Med undtagelse af Charlotte Damgaard/ Ekeblad og hendes promotor Elizabeth Meyer er der kun få af politikerne, der fremstilles med overvægt af sympatiske træk. Søren Schou fremhæver i en artikel om detaljen, at »Snavs er en autenticitetsmarkør af rang« (Schou, 1999, s. 113). Vi har hang til at opfatte fremstillinger af personer som troværdige, hvis deres motiver er flossede $\mathrm{i}$ kanten, egoistiske eller kyniske, frem for hvis de er solidariske og uegennyttige. Det er muligvis derfor, Charlotte Damgaard/Ekeblad virker mindre troværdig på adskillige anmeldere og debattører end hendes mandlige kolleger, der i langt højere grad har snavsede autenticitetsmarkører omkring sig. For hovedparten af de mandlige politikere har omsorgen for deres personlige karriere afløst engagementet i partiet og sagen. Det gælder ikke mindst statsministeren.

Realismen fremkommer dels ved henvisning til konkret eksisterende steder og tider. Dels ved den sproglige, begivenhedsorienterede og modelafhængige tilgang. Læseren kan selv vælge, i hvilken udstrækning, hun vil følge de udlagte spor, hvoraf en del går tæt på de nævnte og andre politikeres private forhold, tilbøjeligheder og ikke mindst deres karakterer og rolle i historieskrivningen, og i hvilken udstrækning hun vil opfatte romanen som en nær-dokumentarisk fremstilling. I alle tilfælde er nøglerne lagt tydeligt til rette gennem realismestrategierne, og i alle tilfælde kan forfatteren hævde, at der naturligvis er tale om fiktion.

Jeg lader Anita Bay Bundegaard fă det sidste ord: »I Danmark ser vi den som en dansk historie, i Sverige genkender de svenske politikere. Den har en universel gyldighed, når det handler om kvindelige toppolitikere, og det er derfor, den er interessant « (Anita Bay Bundegaard i interview med Sarah Skarum, B.T. d. 19.3.2006). Nøgleromanen er således valgt med sans for brug af en universalnøgle.

\section{Politisk drama}

Mens nøgleromanen er en ældre genre, repræsenterer Kronprinsessan en aktuel genremæssig fornyelse i nordisk tv-drama, men også den har sine forudsætninger og genremæssige slægtninge. Samtids- realismen inviterer i højere grad end andre genrer til stillingtagen. Mens det er muligt at indtage en neutral eller refleksiv-nostalgisk tilskuerposition, når man ser Kroniken, er det vanskeligere, når man ser Kronprinsessan. Som det tydeligt fremgår af modtagelsen, tvinger den til stillingtagen a la: Hvordan står det til i dine egne omgivelser? Hvad gør du selv?

I 1970erne og 80erne var samtidsrealismen en stærk tradition i både Danmark og Sverige. Ikke mindst kombineret med krimien blev den eksponent for en kritisk holdning til magten og - ude i periferien - politikerne. Et indflydelsesrigt eksempel er Sjöwahl og Wahlöös Roman om en forbrydelse 1965-75, der blev filmatiseret, og hvis karakterer senere indgik i tv-serien Beck. ${ }^{9}$

Også kønsmagt i omvendingens form har været tematiseret i 1970erne. I dansk sammenhæng foretog Elisabeth Rygaard og Mette Knudsen i Tag det som en mand, frue fra 1975 en satirisk omvending af kønsrollerne, hvor den hjemmegående husmor (Tove Maes) i en drømmesekvens ser sig selv i rollen som magtfuld chef. Men en inddragelse af de mere etablerede politiske niveauer lå langt fra filmens perspektiv - ligesom det lå langt fra den dominerende kvindebevægelses. I 1997 genoptog Mette Knudsen omvendingens tematik i satirekomedien Skat, det er din tur - dog uden den store gennemslagskraft.

Det er først og fremmest amerikansk film, der konfrontativt har tematiseret magt, magtkoncentration og magtmisbrug i politisk sammenhæng, ofte med fokus på præsidenten eller den udøvende magts instanser. Det var tilfældet i Alan Pakulas indflydelsesrige All the President's Men 1976 og The Pelican Brief 1993. Thrilleren har været den oplagte genre for det kritiske fokus. I nyere tids fjernsyn er det magtanalyserende politiske drama blevet videreført i The West Wing 1999-2006, der genoptager Pakula-traditionen og gennemspiller den i en række moralske dilemmaer, der gælder både verdenspolitiske konfrontationer og loyalitetsforhold i staben på det hvide hus. ${ }^{10}$

Kronprinsessans miljø er ligesom The West Wings magtens centrum, og den trækker på alle de konflikter, det afføder, både i det politiske liv og i det private. Men Kronprinsessan er meget mere fokuseret på at afdække mekanismerne ud fra én problemstilling - forholdet mellem køn og magt.

Kongekabale 2004 indoptager og forandrer den politiske thriller i en dansk sammenhæng, så der 
stadig er thrillerelementer i den, men så det politiske drama sættes i front. Instruktøren Nicolaj Arcel og manuskriptforfatteren Rasmus Heisterberg henviser i øvrigt til alle de ovennævnte amerikanske titler som inspirationskilder. ${ }^{11}$ Omdrejningspunkt for Kongekabale er magtspillet på Christiansborg og mediernes omgang med det politiske livs mandlige aktører - og en enkelt kvindelig. Den er bygget på Niels Krause-Kjærs roman af samme navn, der på sin side hentede sit stof i virkeligheden. ${ }^{12}$ Dette stof omsættes i Kongekabale til et angreb på de politikere, der er i deres spindoktorers vold - og på den store del af pressen, der lever tæt omslynget af de politikere, der både er kilde til og modtagere af historierne. Løsningen kommer fra uafhængige, uglesete og kritiske journalister som hovedpersonen, Ulrik Torp, og hans kollega, Henrik Moll.

Kronprinsessan er klart beslægtet med Kongekabale, der på sin side udmærket kan være inspireret af romanen, der jo udkom i 2002. Kronprinsessan og Kongekabale udforsker samme genre, det politiske drama, men de gør det i forskelligt tempo og med forskellige accenter. Kongekabale ligger i sit kapløb med tiden tættere på thrilleren. Kronprinsessan giver sig god tid, især i midterafsnittene. Fællesskabet ligger i gennemlysningen af den problemstilling, der drejer sig om de indfiltrede sammenhænge mellem politik, magt og medier, koncentreret i de politiske partier og deres symbolske arena, parlamentet. I begge tilfælde er det en pointe, at medierne har eller er lige ved at overtage den politiske dagsorden. Det er de i den forstand, at en ikke-medieegnet politiker enten på forhånd bliver filtreret fra eller har besvær med at klare sig; at politikerne er så dybt afhængige af mediernes fremstilling, at de på forhånd indtænker den i lanceringen af deres ideer; $o g$ at mediedækningen under alle omstændigheder bestemmer udfaldet.

Alligevel affærdiges det politiske system ikke. I Kronprinsessan lægger Ekeblad kortene på bordet over for offentligheden i forbindelse med Pandora-skandalen - og rider stormen af i forhold til ministerkollegaerne. Hvad der fælder hende, er privatlivet, der udstilles i sensationspressen: erhvervelsen af en 'sort' lejlighed til ægtemanden og 'privatkørslen' for skatteydernes regning mellem hjem og børnehave. Men pointen er, at Ekeblad kommer igen - denne gang stemt ind i Riksdagen af folket. I Kongekabale får pressens fokus på privatlivet endnu mere fatale konsekvenser. Den fungerende næstformands mand bliver med fuldt overlæg sat i et uheldigt lys af pressen og begår selvmord. Men den kritiske journalistik sejrer til sidst - på tværs af de etablerede journalisters netværk og modstand.

Både Kongekabale og Kronprinsessan bygger på litterære forlæg i romanform, der som vist inddrager genkendelige steder, begivenheder, en kausal dramaturgi, et overbevisende samtidsnært sprog og genkendelige modeller. Grundlæggende anvender de samme realismestrategier som romanerne. Det er dog bemærkelsesværdigt, at titlerne i alle tilfælde angiver det universelle perspektiv, der kan udgøre et alibi, hvis nogen skulle synes, at fiktionen bliver for nærgående. Udtrykket 'kongekabale' har ligesom 'kongemager' været kendt siden tidernes morgen, når en ny regent skulle udpeges og andre emner ryddes til side, og 'kronprins' er en almindeligt udbredt betegnelse for en mulig efterfølger. Kronprinsesse afviger ved at angive det feminine perspektiv. I Kongekabale er Det konservative Folkeparti forvandlet til »Midterpartiet«, dels for på samme måde at angive den universelle problemstilling, dels som en ironisk kommentar til konkurrencen i dansk politik om at befinde sig på midten.

Det politiske drama udvikler sig fortsat i tv, f.eks i Forbrydelsems alliance mellem mord og kommunalpolitik.

\section{Dobbeltkontrakter og referencerammer}

I Dobbeltkontrakten er det Poul Behrendts hovedtese, at der for øjeblikket foregår en nedbrydning af den traditionelle kontrakt mellem forfattere og læsere. Den traditionelle kontrakt går ud på, at enten har vi med sagprosa at gøre, og så kan forholdene dokumenteres. Eller også har vi med fiktion at gøre, og så er det hverken muligt eller relevant at dokumentere. Med eksempelmateriale fra bl.a. Peter Høeg (De måske egnede 1993), Thorkild Hansen (Et atelier i Paris 1-2 1990) Suzanne Brøgger (Fadekatten 1997), Jan Stage (De andres krig 1997) og Claus Beck-Nielsen, der eksperimenterer med sin egen eksistens, tegner Behrendt et billede, hvor en såkaldt dobbeltkontrakt har erstattet de gammeldags kontrakter mellem forfattere og læsere. Dobbeltkontrakten er i kort begreb kendetegnet ved forfatterens dobbeltrettede udsagn om et værk, nemlig, »at alt, hvad der stod i det, var sandt og foregået i virkeligheden, samt - at alt var fiktion « (Behrendt, 2006, s. 24). Dobbeltkontrakten sætter førstegangslæseren i et dilemma på grund af den 
tidsforskydning, der ofte ledsager lanceringen, og forfatteren slører altså bevidst grænserne mellem fakta og fiktion.

Hanne-Vibeke Holst kan i modsætning til en række af sine kolleger ikke anklages for at spille på en dobbeltkontrakt i Kromprinsessen. Hun udnytter blot realismestrategierne, herunder nøgleromanens traditionelle greb. Og hun har haft et taknemmeligt publikum, idet en række af hendes læsere - og Kronprinsessans seere - med kyshånd har grebet den dobbelthed, nøgleromanen lever af, og tolket virkeligheden ind i både roman og tv-føljeton. Både Kronprinsessen og Kronprinsessan trækker meget bevidst på en dobbelt referenceramme, der ikke forsmår nogen lejlighed til at indmontere genkendelige træk ved hjælp af sine stadige referencer til såvel den medieformidlede virkelighed som personer, begivenheder, steder og tider, vi kender fra virkeligheden - og det både fra det politiske liv og fra privatlivet.

Derimod indeholder efterfølgeren, Kongemordet fra 2005, der også kaldes en »Roman«, ubehageligt nærgående træk i sit portræt af den finansminister, der vælter statsministeren / partiformanden. Karakteren minder meget stærkt om Mogens Lykketoft - selv om der er lige så mange træk, der modsiger en sådan association. ${ }^{13}$ Romanens modstilling mellem magtbrynde og magtesløshed bliver tegnet op ved hjælp af ekstremer. Modsætningen går mellem på den ene side en voldelig ægtemand, der samtidig er en succesrig, blændende dygtig politiker, og på den anden side en voldsramt kone og en ung kvindelig studentermedhjælper af tyrkisk oprindelse. Men først og fremmest er der tale om en spektakulær udstilling af magtens psykologi i et karakterportræt, der nemt forfører til at forveksle fiktion og virkelighedsinspiration.

Forholdet mellem interesse og udlevering, appel til modtagerens kønsbevidste og politiske engagement og til samme modtagers nyfigenhed og hang til sladder, udgør et etisk vanskeligt felt. Hvor Kronprinsessan klarer balancen, er den ved at tippe i Kongemordet.

\section{Noter}

1 I det følgende betegner jeg for præcisionens skyld tvføljetonen med titlen Kronprinsessan og Hanne-Vibeke Holsts danske forlæg med titlen Kronprinsessen.

2 Annica Sjögren i drama@svt.se

3 Marie Peterson skriver således: "Det är inte ofta verkligheten läcker in och stör recensionsarbetet. Men i dag känns det svårt och underligt at skriva om en roman som heter "Kronprinsessan" och som handlar om en kvinnlig miljöminister" (Dagens Nyheter d. 13.9.2003). Anna Lindh blev myrdet d. 11.9.2003.

4 F.eks. Jan-Olov Andersson i Aftonbladet d. 27.2.2006: "Förlagan är danskan Hanne-Vibeke Holsts roman. Hun lär ha haft Mona Sahlin-affären som inspirationskälla för historien om Charlotte Ekeblad" og Jesper Björnstedt Quarsell i foromtale i Stockholm City d. 9.2.2006: "TV-serien bygger på en bok av den danske författeren Hanne-Vibeke Holst som har just Mona Sahlins karriär som inspiration".

5 Ved vurderingen af dette udsagn må man tage i betragtning, at Ekspressen repræsenterer den avistype, som Kromprinsessan utvetydigt angriber.

6 Oplyst af forfatteren under Vendsyssel Litterære Selskabs temadag i Tolne d. 19.8.2006, bekræftet i mailkorrespondance med mig d. 25.8.2006. Citatet er fra denne korrespondance. Desuden har Hanne-Vibeke Holst stillet afslagsbrevet fra TV-Drama af 17.6.2002 til rådighed for mig.

7 Kilde: Eva Novrup Redvall: Interview med Katrine Windfeld i Information d. 3.3.2006.

8 Manuskriptforfatterne er Sara Heldt og Pia Gradvall, begge veteraner som episodeforfattere på svenske populære serier (f.eks. Rederiet 1992).

9 En historisk kortlægning af samtidsrealisme og krimitraditioner i TV-drama findes i Agger 2005 a).

10 Se Kristina Riegert, 2005.

11 Se Christian Monggaards interview »Magtspin« i EKKO nr. 23, 2004.

12 Bl.a. Hans Engells berømte promillekørsel i 1997, der førte til hans afgang som leder af Det konservative Folkeparti og efterfølgende en række problemer med interne stridigheder i parti og folketingsgruppen.

13 Ifølge Holst selv har hun bestræbt sig på at indlægge andre associationer (møde i Tolne d. 19.8.2006). Kongemordet er andet led i den trilogi, der begyndte med Kromprinsessen og skal afsluttes med Dronningerunden. Kongemordet er under indspilning med samme hold som Kronprinsessen. 


\section{Litteratur}

Agger, G. (2005a). Dansk tv-drama. Arvesolv og underholdning. Frederiksberg: Samfundslitteratur.

Agger, G. (2005b). Kon i Matador og Kroniken. Aalborg: Freia (tilgængelig på www.ihis.aau.dk/freia).

Behrendt, P. (2006). Dobbeltkontrakten. København: Gyldendal.Bandes, G. (1963). 'Det uendeligt Smaa' og 'det uendeligt Store' i Poesien. I Svendsen, W. (red.). Georg Brandes. Essays. København: Gyldendal.

Borchorst, A. (2004). Skandinavisk ligestillingspolitik tur-retur - på dansk billet. Nytt Norsk Tidsskrift, 3-4, 264-274.

Holmgaard, J. (1998). Teoriens topik. København: Medusa.

Holst, H.V. (2003). Kronprinsessen. København: Gyldendals Bogklubber.

Holst, H.V. (2006). Kongemordet. København: Gyldendals Bogklubber.

Kabel, L. \& Sparre, K. (2001). Den glade journalistik. Om mediernes dakning af de kendte. Århus: CFJE.

Langkjær, B. (2002). In Jerslev, A. (Ed.). In Realism and Danish Cinema. Realism and 'Reality' in film and Media. Northern Lights. Film and Media Studies Yearbook (pp. 15-40). Copenhagen: Museum Tusculanum Press.
Lukacs, G. (1971). Essays über Realismus. In Georg Lukacs Werke Band 6. Neuwied: Luchterhand.

Monggaard, C. (2004). Magtspin. EKKO, 23, 38-41.

Riegert, K. (2005). The Ideology of the West Wing: The TV Show that Wants to Be Real. Paper til Den 17. Nordiske Medieforskerkonference, Aalborg d. 11.14.8.2005.

Schou, S. (1999). Mimesis og den realistiske detalje. I Sejten, A. E. \& Svendsen, E. (Red.): Detaljen (pp. 108-116). Frederiksberg: Roskilde Universitetsforlag.

Wilpert von, G. (1964). Sachwörterbuch der Literatur. Stuttgart: Alfred Kröner Verlag.

Referencer til anmeldelser, presseomtale og interviews fremgår af brødtekst eller noter.

Gunhild Agger er lektor ved Institut for Kommunikation, Aalborg Universitet. 